\title{
Diagnostic Imaging. Pediatrics
}

\author{
L.F. Donnelly • B.V. Jones • S.M. O'Hara • C.G. Anton • C. Benton • S.J. Westra • S.J. Kraus \\ J.L. Strife • B.L. Koch • K.L. Hoeg • E.J. Crotty • R.B. Fortuna \\ Amirsys Inc, Salt Lake City, Utah (2005) \\ ISBN 1-4160-2333-X; ISBN 0-8089-2324-2 (International English Edition)
}

In the online version of the book review unfortunately G. Beluffi was not listed as the Author.

The original version of the article can be found at:

http://dx.doi.org/10.1007/s11547-006-0114-4

G.Beluffi,

U.O.S. di Radiologia Pediatrica, U.O.C. di Radiodiagnostica, Fondazione IRCCS Policlinico San Matteo, Piazzale Golgi, 19, I-27100 Pavia 